\title{
Museum Websites and Museum Visitors: Before and After the Museum Visit
}

Paul F. Marty

College of Information

Florida State University

240 Louis Shores Building

Tallahassee, FL 32306-2100, USA

850.644 .5133

850.644 .6253 (fax)

marty@ci.fsu.edu

\begin{abstract}
This article presents results from an exploratory survey (administered to more than 1200 visitors at nine different online museums) that addressed questions about the role of museum websites in the lives of museum visitors. The results provide details about the use of museum websites before and after the museum visit, and indicate that online visitors frequently use museum websites to complement their visits to physical museums. The article helps museum researchers and professionals better understand the cyclical relationship that exists between museums and museum websites, and provides strategies for supporting the changing information needs of museum visitors before and after museum visits.
\end{abstract}

\section{Keywords}

Museum websites; museum visitors; pre- and post-visit activities; visitor studies.

\section{Notice}

This is the author's version of a work that was accepted for publication in Museum Management and Curatorship. Changes resulting from the publishing process, such as peer review, editing, corrections, structural formatting, and other quality control mechanisms may not be reflected in this document. Changes may have been made to this work since it was submitted for publication. A definitive version was subsequently published in Museum Management and Curatorship, 22 (4), 337-360. http://dx.doi.org/10.1080/09647770701757708 


\section{Introduction}

A positive, complementary relationship between museums and museum websites is extremely important for museum professionals and museum visitors. Museum websites should lure online visitors into the museum's collections virtually and inspire them to visit the museum in person. Visitors to physical museums should feel similarly inspired to visit the museum's website, using the website as a bridge to connect their pre-visit and post-visit activities by learning more about the museum and its collections. If all goes well, the resulting feedback loop should lead to increased visitation and overall visitor satisfaction.

Cultivating this kind of cyclical relationship can be very difficult, despite its benefits for museums and their visitors. Designing museum websites that complement physical museums poses challenges for museum professionals, only some of which are technical (Coburn and Baca 2004; Cunliffe, Kritou, and Tudhope 2001; Dyson and Moran 2000). Encouraging museum visitors to make museum websites a part of their everyday lives is also very challenging (Taxén and Frécon 2005). To explore these problems, a number of researchers have studied the relationships between museums, museum websites, and museum visitors (Kravchyna and Hastings 2002; Thomas and Carey 2005).

This article builds upon existing research by exploring how museum professionals can use museum websites to build stronger relationships with museum visitors, before and after they visit museums. It focuses on how museum professionals can encourage a cyclical, complementary relationship where visitors to museum websites are inspired to visit physical museums, and visitors to physical museums are inspired to visit museum websites. It stresses the need to explore how visitors can be encouraged to form lifelong relationships with museums, visiting in person when they can, and visiting online when they cannot.

The results presented below represent one half of an exploratory survey that was administered to more than 1200 visitors at nine different online museums and addressed the relationship between museums and museum websites in the lives of museum visitors (results from the other half of this study will be presented in a separate article). The survey questions reported in this article asked respondents about the circumstances in which they visit museum websites before and after visiting museums, their needs and expectations when visiting museum websites before and after visiting museums, and the extent to which museum websites influence their decision to visit a museum. The results of the survey help museum professionals and researchers better understand the complementary relationship that exists between museums and museum websites.

\section{Literature Review}

The past few decades have witnessed unprecedented changes with respect to the use of museum information resources - changes that have resulted in new levels of access and new forms of interactivity for museum professionals and museum visitors (Besser 1997; Knell 2003). These changes have manifested most clearly in the relationships between museums, museum websites, and museum visitors (Müller 2002).

Digital collections and interactivity 
Digital collections and online exhibits offer new ways to draw people into museums and build stronger relationships between museums and their visitors (Cameron 2003; Lynch 2002). When the Minneapolis Institute of Arts restored one of their paintings in 1999, they made it possible for the museum's visitors to follow the restoration online in real time (Sayre 2000). This approach was so popular, and the museum's visitors were so entranced by the way this website drew them into the process and helped them learn more about the museum's behind-the-scenes activities, that the Minneapolis Institute of Arts repeated the project five years later with a different painting (http://www.artsmia.org/restoration-online). Similar projects, such as the online restoration of Sue the T. Rex at the Field Museum (http://www.fieldmuseum.org/sue), testify to the power of integrating behind-the-scenes activities and online exhibits.

New forms of interactivity provide museum visitors with countless opportunities for learning and exploration (Hamma 2004). Today's museum visitors are encouraged to interact with museum collections in ways impossible in the past. Using a variety of interactive tools, online visitors can "strip away" layers of paintings, examining earlier versions through infrared or x-ray lens, and determining the exact material composition of any pigment used on a painting (Douma and Henchman 2000). Online visitors to the National Museum of American History can manipulate a collection of digital artifacts, looking for connections along temporal, cultural, and thematic lines by using an innovative interface to group artifacts with common characteristics (Gillard 2002). A growing number of museums, including the Metropolitan Museum of Art and the Fine Arts Museums of San Francisco, allow visitors to create personal digital collections of their favorite artifacts, adding or removing artifacts at will, and returning to view their collections whenever they like (Bowen and Filippini-Fantoni 2004).

Interactive projects such as these tear down old barriers of information access and have the potential to revolutionize the way museum visitors approach museum objects. They have removed certain restrictions of space and time that historically have constrained artifacts and collections to individual museums or galleries. Using digital surrogates, museum visitors can interact with artifacts from diverse collections regardless of the physical location of each artifact. Advances in interactivity have removed barriers between public access and behind-the-scenes activities, allowing visitors to see what it would be like to curate an exhibit (Adams et al. 2001). They have helped remove the physical barriers that separate "inside the museum" from "outside the museum," thereby blurring the boundaries between in-house and online museum visits (Galani and Chalmers 2002).

\section{Online visitors and museum visits}

The changing interactions between museums and their visitors concern many museum professionals, especially given how little is known about how new forms of interactivity affect the online/onsite relationship museum visitors have with museums (Haley Goldman and Wadman 2002). For example, museum professionals often face a common worry when planning to provide access to digital museum resources. The concern focuses on whether museums providing online access to their collections will see a corresponding decrease in physical visits. At some stage in the planning process, someone usually asks, "if visitors can access our digital collections using the Internet, will they still come to the museum in person?" 
The commonsense answer to this question is that, to the best of current knowledge, online visitors are also physical visitors. Logically, this makes sense; no one asks: "If people can look at pictures of beaches online, will they still vacation in Florida?" In theory, the ability to access virtual museum resources online should serve as a lure, encouraging potential museum-goers to visit the physical installation. But is this true? Haley Goldman and Wadman wrote,

"The relationship between virtual museum sites and physical sites has not been extensively researched. [...] Museum Web site staff that we spoke with felt that the museum Web site boosted attendance for the physical museum, but they had no concrete evidence to prove it. While there are no studies disproving the commonsense approach, one can always have more studies with solid, detailed data that backs up this theory" (Haley Goldman and Wadman 2002; cf. McKenzie 1997).

Recently, a number of surveys have provided compelling evidence that online museums actually drive physical museum attendance instead of discouraging physical visits; in the majority of studies, planning a museum visit is consistently cited as the primary reason people visit museum websites (Haley Goldman and Schaller 2004; cf. Bowen, Bennet, and Johnson 1998; Chadwick and Boverie 1999). Kravchyna and Hastings (2002) found that 57\% of museum website users visit museum websites both before and after they visit physical museums. Similarly, Thomas and Carey (2005) found that $70 \%$ of museum visitors specifically looked for online information prior to a museum visit, and that $57 \%$ said the information they found online increased their desire to visit the museum in person.

There has also been a tremendous increase in knowledge about online museum visitors in general (Herman, Johnson, and Ockuly 2004; cf. Sarraf 1999). Research into the characteristics and behaviors of museum visitors, whether those visitors are in the museum or online or both, is extremely important for museum professionals (Booth 1999; Falk 2006; Falk and Dierking 2000). For example, Bowen (1999) found that museum visitors, while traveling, were more likely to visit physical museums not in their home town if they had already visited those museums' websites. Such data can provide an increasingly clear picture of the characteristics of online visitors and their visits to museum websites capable of helping all museum professionals improve their relationships with their visitors, online or in-house.

Despite the accumulated data and evidence, concerns about the relationship between museums, museum websites, and museum visitors are still being raised. Why? These concerns are unlikely to arise because museum professionals are unaware of these studies, or that too few studies have been performed. These concerns arise because the unanswered questions about museums, museum websites, and museum visitors are more complicated than whether online visitors will also visit physical museums.

\section{The museum website in the life of the visitor}

The question that needs to be explored is: "what role does the museum website play in the life of the museum visitor, before and after museum visits?" This is difficult to answer because not enough is known about how people interact with online museum resources in their daily lives, or 
how online museum visitors relate to museum websites, before and after museum visits (cf. Marty 2007). While prior studies (described above) have demonstrated conclusively that a complementary relationship exists between museums and museum websites, that museums and museum websites are not mutually exclusive, and that visiting museum websites cannot replace visiting museums, more studies are needed that explore questions such as: Why do people visit museum websites? How do museum websites influence the visitor's decision to visit museums? What do visitors want from museum websites before and after museum visits?

Answering these questions becomes more important as more museums offer extensive digital resources online, and as the number of online museum visitors increases to be as much as ten times the number of physical visitors. If museum professionals wish to encourage a strong relationship between museums, museum websites, and museum visitors, it is important to answer these questions. If museum professionals want their visitors to make museums part of their everyday lives, where they are coming to the museum when they can, and visiting the museum's website when they cannot, it is important to answer these questions. If museum professionals want their visitors to feel connected to the museum whether they are physically there or not, it is important to answer these questions. There is a critical need, therefore, for studies that explore the role of museum websites in the lives of museum visitors.

\section{Research Questions and Methods}

This study presents results from an exploratory survey designed to address the following research question: What role do museum websites play in the lives of museum visitors, before and after museum visits?

Answering this question involved addressing a number of related research questions, including: Why do people visit museum websites before or after visiting museums? What information do museum visitors expect to find on museum websites? What is the impact of museum websites on museum visitation? How can museums use museum websites to build stronger relationships with their visitors?

To answer these research questions, the researcher developed an online survey that asked respondents about the circumstances in which they visit museum websites before or after visiting museums, their needs and expectations when visiting museum websites before or after visiting museums, and the extent to which museum websites influence their decision to visit a museum.

As discussed below in Limitations, the exploratory survey instrument was intentionally designed to replicate the feel of a structured interview schedule, thereby allowing the study to reap the benefits of both survey and interview methods, while simultaneously minimizing the inherent limitations of online research. The survey questions listed below were presented to the research participants in form of a structured interview that guided each respondent through a discussion of the relationship between museums and museum websites in their everyday lives.

Respondents were asked "In general, before visiting a museum, how likely are you to visit the museum's website?" This question employed a five-point Likert scale ranging from Very Unlikely to Very Likely. 
Respondents were then asked to indicate how likely they were to visit a museum's website before visiting the museum in certain situations. This question employed a five-point Likert scale ranging from Very Unlikely to Very Likely, and listed the following specific situations:

- You are visiting a museum you visit regularly

- You are visiting a museum unfamiliar to you

- You are visiting a museum by yourself

- You are visiting a museum with friends or family

- You are visiting a museum in your home town

- You are visiting a museum while traveling or on vacation

- You are visiting a museum where the exhibits change frequently

- You are visiting a museum where there is too much to see in one visit

Respondents were also asked to indicate how likely they were to use certain kinds of online museum resources when visiting a museum's website before visiting the museum. This question employed a five-point Likert scale ranging from Very Unlikely to Very Likely, and listed the following online resources:

- Online images of artifacts / collections data

- Online tours of galleries / interactive exhibits

- Online educational activities / learning resources

- Online research materials / archives

- Information about hours of operation / location / directions

- Information about admission fees / pricing

- Information about museum facilities / gift shop / restaurants

- Information about current and future exhibits

- Information about programs / tours / special events

- Information about employment / volunteer opportunities

- Information about donation / membership opportunities

These same three questions were then repeated to ask the respondents about their use of museum websites after visiting a museum. The same five-point Likert scales were used, and the same possible responses offered for each question (with minor edits for changes in tense).

Respondents were asked to indicate whether their decision to visit a museum has ever been influenced specifically because of the museum's website, answering Yes or No to the following two questions:

- Have you ever decided to visit a museum specifically because of its website? 
- Have you ever decided not to visit a museum specifically because of its website?

Respondents were asked "How likely are you to use a museum's website to decide whether you want to visit that museum?" This question employed a five-point Likert scale ranging from Very Unlikely to Very Likely.

Respondents were asked to indicate how likely their decisions to visit (or not visit) museums are influenced by certain characteristics of museum websites. This question also employed a fivepoint Likert scale ranging from Very Unlikely to Very Likely, and listed the following specific website characteristics:

- Quality of information available

- Quality of images / graphics

- Ability to navigate / browse website

- Ability to search website / collections

- Ease of use / usability / accessibility of website

- Performance / efficiency / reliability of website

To see how these questions related to the visitors' general attitudes toward and experiences with museums and museum websites, respondents were asked several demographics questions to determine the types of museum visitors who participated in the study, and to classify the respondents in terms of their levels of interactions with museums; these questions were:

- How frequently do you visit museums?

- How frequently do you visit museum websites?

- From your perspective, how important is it for a museum to have a museum website?

To reach as many participants as possible, the researcher used several museum listservs to call for volunteers to help disseminate the study, and nine different international museums volunteered to advertise the survey on their websites; these museums were:

- the Fine Arts Museums of San Francisco (http://www.famsf.org/);

- the Science Museum of Minnesota (http://www.smm.org/);

- the Australia War Memorial Museum (http://www.awm.gov.au/);

- the Victoria and Albert Museum (http://www.vam.ac.uk/);

- the National Museum of Wildlife Art (http://www.wildlifeart.org/);

- the Fruitlands Museum (http://www.fruitlands.org/);

- the Royal Armouries (http://www.royalarmouries.org/);

- the Art Complex Museum (http://www.artcomplex.org/); and

- the Tryon Palace (http://www.tryonpalace.org/). 
Each of these museums placed a link to the online survey on their home page, using text similar to the following: "Interested in the relationship between museums and museum websites? Click here to tell us what you think." Having so many different types of museums agree to promote this study was extremely helpful for getting a wide range of responses from online museum visitors, and their locations around the world brought an international aspect to this study unparalleled in prior research.

The results from the survey were processed using SPSS (originally, Statistical Package for the Social Sciences), which generated descriptive statistics for each of the above survey questions. Correlation coefficients (Spearman's rho) and Pearson's chi-squares were also calculated to provide comparative statistics useful for exploring the influence of the type of museum and the type of museum visitor on the relationship museum visitors have with museums and museum websites.

\section{Limitations}

The use of exploratory survey methods has limitations that directly reflect the difficulties of conducting research and gathering data about online museum visitors. Meta-analyses of online survey research show that obtaining a random sample or acquiring representative data from online surveys is extremely difficult if not impossible (Andrews, Nonnecke, and Preece 2003; Couper 2000). On the other hand, acquiring in-depth qualitative interview data from thousands of research participants visiting nine different museum websites in different countries around the world is equally impossible. Therefore, this study took the logical middle ground of using an exploratory survey where the survey instrument takes the place of a structured interview schedule, thereby allowing the researcher to access a larger number of participants than would be possible in a purely semi-structured or unstructured interview study without falling prey to the problems of representation that plague attempts at random sampling using online surveys.

Considering the limitations of online research, exploratory survey research is often the only practical method available when gathering information from online visitors to museum websites (Haley Goldman and Schaller 2004). In this study, the use of an exploratory survey research method restricted respondents to people who a) were already visiting museum websites, and b) chose to answer a survey about museums and museum websites. In addition, the placement of the survey link on each museum's home page may have introduced an unintentional bias as it is possible that visitors to a museum's home page are more likely to be planning a museum visit than visitors to other pages on a museum's website. Also, the survey's focus on museum visitation may have biased the results for those online visitors who have no intention of visiting physical museums. While these restrictions place limitations on the generalizability of this research to museum visitors overall, the following results shine a valuable light on the mindset of online museum visitors as a distinct and important research population.

\section{Results}

The online survey was administered from October 2005 to October 2006; there were 1215 valid responses to the survey (out of 1464 total responses) during this time period. For the purposes of this study, survey responses were considered valid if respondents answered at least one question 
other than the demographics questions. Not every respondent provided a response to every question, and therefore specific n's are presented for each result below, and the missing responses were factored out of the comparative analyses performed.

\section{Respondent characteristics}

Each of the 1215 respondents who completed the online survey was directed to the study from one of nine different museums. 422 (34.7\%) respondents originated from the Australia War Memorial Museum, 353 (29.1\%) from the Fine Arts Museums of San Francisco, 282 (23.2\%) from the Victoria and Albert Museum, 51 (4.2\%) from the Royal Armouries, 41 (3.4\%) from the Science Museum of Minnesota, 29 (2.4\%) from the National Museum of Wildlife Art, 16 (1.3\%) from the Tryon Palace, $12(1.0 \%)$ from the Fruitlands Museum, and $9(0.7 \%)$ from the Art Complex Museum $(n=1215)$. The inherent unreliability of web metrics and page view statistics for determining visitation rates (Sen, Dacin, and Pattichis 2006), combined with the inability to know whether any given visitor to the website actually saw the link to the survey, makes it impossible to provide any reliable data about survey response rates beyond this distribution of respondents.

As part of the survey, the respondents were asked to answer several questions related to the visitors' general attitudes toward and experiences with museums and museum websites. Their answers to these questions provide some indication of the types of interactions the online museum visitors who responded to this survey have with museums and museum websites:

- When asked "How frequently do you visit museums?", 13.5\% (163) responded Rarely, 16.4\% (197) Annually, 30.5\% (367) Quarterly, 27.8\% (335) Monthly, 8.9\% (107) Weekly, and 2.9\% (35) Daily ( $\mathrm{n}=1204)$.

- When asked "How frequently do you visit museum websites?", 12.3\% (147) responded Rarely, 4.8\% (57) Annually, 14.9\% (179) Quarterly, 28.4\% (341) Monthly, 30.5\% (366) Weekly, and 9.2\% (110) Daily $(\mathrm{n}=1200)$.

- When asked "From your perspective, how important is it for a museum to have a museum website?", 4.4\% (53) responded Very Unimportant, 0.2\% (3) Unimportant, 4.0\% (48) Neutral, 22.0\% (264) Important, and 69.4\% (834) Very Important ( $\mathrm{n}=1202)$.

The typical online museum visitor completing this online survey, therefore, visits museums approximately four times a year, visits museum websites approximately once a week, and considers it very important for museums to have museum websites.

\section{Descriptive statistics}

Table 1 shows the summary of responses provided when respondents were asked how likely they were in general to visit a museum's website before visiting the museum. According to the survey results, online museum visitors generally visit museum websites before they visit museums, with the vast majority $(81.9 \%)$ of the survey respondents saying that they were either likely or very likely to do so. 


\section{[INSERT TABLE 1]}

Table 2 shows the summary of responses provided when respondents were asked how likely they were to visit a museum's website before visiting the museum in certain situations. According to the survey results, online museum visitors are likely to visit museum websites prior to a museum visit in almost all of the surveyed circumstances. Survey respondents were most likely to visit a museum's website before visiting a museum when visiting museums unfamiliar to them $(89.0 \%$ likely or very likely to do so), museums where the exhibits change frequently ( $88.2 \%$ likely or very likely to do so), and museums where there is too much to see in one visit ( $83.5 \%$ likely or very likely to do so). They were least likely (although still likely) to visit a museum's website before visiting a museum when visiting museums they visit regularly $(59.5 \%$ likely or very likely to do so).

Survey respondents were more likely to visit a museum's website before visiting a museum when visiting museums while traveling or on vacation ( $81.0 \%$ likely or very likely to do so) than when visiting museums in their home town (61.7\% likely or very likely to do so). Survey respondents were also slightly more likely to visit a museum's website before visiting a museum when visiting museums with friends or family ( $80.5 \%$ likely or very likely to do so) than when visiting museums by themselves ( $77.9 \%$ likely or very likely to do so).

\section{[INSERT TABLE 2]}

Table 3 shows the summary of responses provided when respondents were asked how likely they were to use certain online resources when visiting museum websites before visiting museums. According to the survey results, online museum visitors who are visiting a museum's website prior to a museum visit are more likely to use basic information such as hours of operation, driving directions, or information about current exhibits, than they are to use online images of artifacts, online gallery tours, or online educational activities. Prior to visiting museums, survey respondents were most likely to use information about hours of operation, location, and directions (92.7\% likely or very likely to do so), information about current and future exhibits ( $91.8 \%$ likely or very likely to do so), and information about admission fees and pricing (87.2\% likely or very likely to do so). Survey respondents were also likely to use information about programs, tours, and special events (79.7\% likely or very likely to do so), as well as information about museum facilities, gift shops, and restaurants (64.2\% likely or very likely to do so). On the other hand, prior to visiting a museum, survey respondents were very unlikely to use information about employment and volunteer opportunities (only $24.4 \%$ likely or very likely to do so), or information about donation and membership opportunities (only $27.1 \%$ likely or very likely to do so).

While online museum visitors are generally likely to use online resources prior to visiting a museum, survey respondents were less likely to use such resources than they were to access basic information resources online. Prior to visiting a museum, survey respondents were relatively likely to use online images of artifacts and collections data $(69.3 \%$ likely or very likely to do so), and online tours of galleries and interactive exhibits (61.0\% likely or very likely to do so). On the other hand, survey respondents were generally less likely to use online research 
materials and archives (53.9\% likely or very likely to do so), and online educational activities and learning resources (43.2\% likely or very likely to do so) when visiting a museum's website prior to visiting the museum.

\section{[INSERT TABLE 3]}

Table 4 shows the summary of responses provided when respondents were asked how likely they were in general to visit a museum's website after visiting the museum. According to the survey results, the majority of online museum visitors generally visit museum websites after they visit museums, although they are less likely to visit museum website after visiting museums than they are to do so before visiting museums. $69.5 \%$ of the survey respondents were either likely or very likely to visit a museum's website after visiting the museum.

\section{[INSERT TABLE 4]}

Table 5 shows the summary of responses provided when respondents were asked how likely they were to visit a museum's website after visiting the museum in certain situations. According to the survey results, online museum visitors are likely to visit museum websites after a museum visit in almost all of the surveyed circumstances, although in each case they are less likely to do so than they are before visiting museums. Survey respondents were most likely to visit a museum's website after visiting a museum when visiting museums where there is too much to see in one visit (79.6\% likely or very likely to do so), and museums where the exhibits change frequently ( $79 \%$ likely or very likely to do so). They were least likely (and the only situation where the majority of respondents were not likely to do so) to visit a museum's website after visiting museums in their home town (only $47.8 \%$ likely or very likely to do so).

Survey respondents were more likely to visit a museum's website after visiting a museum when visiting museums unfamiliar to them (72.0\% likely or very likely to do so) or when visiting museums while traveling or on vacation $(70.6 \%$ likely or very likely to do so) than when visiting museums they visit regularly (57.9\% likely or very likely to do so). Survey respondents were slightly more likely to visit a museum's website after visiting a museum when visiting museums by themselves (59.3\% likely or very likely to do so) than when visiting museums with friends or family (55.0\% likely or very likely to do so) - the exact opposite of the same situations when visiting a website before visiting a museum.

\section{[INSERT TABLE 5]}

Table 6 shows the summary of responses provided when respondents were asked how likely they were to use certain online resources when visiting museum websites after visiting museums. According to the survey results, online museum visitors who are visiting a museum's website after visiting a museum are less likely to use basic information such as hours of operation and admission fees, and more likely to use online images of artifacts, collections data, and research materials. After visiting museums, survey respondents were most likely to use information about current and future exhibits (79.6\% likely or very likely to do so), and information about programs, tours, and special events (68.5\% likely or very likely to do so). On the other hand, they were very unlikely to use information about hours of operation, location, and directions 
(only $32.6 \%$ likely or very likely to do so), information about admission fees and pricing (only $28.9 \%$ likely or very likely to do so), and information about museum facilities, gift shops, and restaurants (only $26.3 \%$ likely or very likely to do so). Survey respondents remained very unlikely to use information about employment and volunteer opportunities (only $29.4 \%$ likely or very likely to do so), or information about donation and membership opportunities (only $26.2 \%$ likely or very likely to do so).

Online museum visitors are generally more likely to use online resources such as collections data or research materials after visiting a museum than they are to use the same resources prior to visiting a museum. After visiting a museum, survey respondents were particularly likely to use online images of artifacts and collections data (72.4\% likely or very likely to do so), as well as online research materials and archives (67.0\% likely or very likely to do so). Survey respondents were generally less likely (although still likely) to use online tours of galleries and interactive exhibits (53.8\% likely or very likely to do so), and online educational activities and learning resources (53.8\% likely or very likely to do so) when visiting a museum's website after visiting the museum.

\section{[INSERT TABLE 6]}

Table 7 shows the summary of responses provided when respondents were asked whether they had ever decided to visit or not visit a museum specifically because of the museum's website. According to the survey results, online museum visitors generally do not decide whether or not to visit museums specifically because of the museum's website. On the other hand, online museum visitors are nearly twice as likely to decide to visit a museum because of its website than they are to decide not to visit a museum because of its website. $39.6 \%$ of the survey respondents reported that they had decided to visit a museum specifically because of its website (with $60.4 \%$ responding in the negative), while only $19.7 \%$ of the survey respondents reported that they had decided not to visit a museum specifically because of its website (with $80.3 \%$ responding in the negative).

\section{[INSERT TABLE 7]}

Table 8 shows the summary of responses provided when respondents were asked how likely they were to use a museum's website to decide whether they want to visit a museum. According to the survey results, the majority of online museum visitors consider museum websites to be a deciding factor in their decisions to visit museums: $69.9 \%$ of the survey respondents were likely or very likely to use a museum's website to decide whether they want to visit a museum.

\section{[INSERT TABLE 8]}

Table 9 shows the summary of responses provided when respondents were asked how likely certain specific characteristics of museum websites were to influence their decision to visit or not visit a museum. According to the survey results, online museum visitors are likely to consider almost all aspects of a museum's website when deciding whether to visit a museum. The characteristic of museum websites most likely to influence the decision to visit a museum was the quality of information available online, with $77.2 \%$ of the survey respondents saying this 
characteristic was likely or very likely to do so. The characteristic of museum websites least likely (although still likely) to influence the decision to visit a museum was the ability to search the website and collections, with $59.8 \%$ of the survey respondents saying this characteristic was likely or very likely to do so.

Other characteristics of museum websites likely to influence the online museum visitor's decision to visit a museum included the quality of images and graphics, with $62.2 \%$ of the survey respondents saying this characteristic was likely or very likely to do so; the ability to navigate and browse the website, with $62.4 \%$ of the survey respondents saying this characteristic was likely or very likely to do so; the ease of use, usability, and accessibility of the website, with $64.8 \%$ of the survey respondents saying this characteristic was likely or very likely to do so; and the performance, efficiency, and reliability of the website, with $63.7 \%$ of the survey respondents saying this characteristic was likely or very likely to do so.

\section{[INSERT TABLE 9]}

\section{Comparative statistics}

A number of comparative analyses were run on the above results, including Spearman's rho and Pearson's chi-squares. The large number of questions asked on this survey meant that thousands of statistical analyses were performed in preparing this article. Given space considerations, it is impossible to present even a small fraction of these analyses, and therefore this section will highlight only the most notable results from the comparative statistics.

An examination of the characteristics of the online museum visitors who completed the survey, and the influence of these characteristics on the survey results, shows that the type of interactions survey respondents have with museums and museum websites have some but no major effects on the role museum websites play in their everyday lives. When comparing survey results with the museum from which the survey respondents originated, for example, the statistical analysis showed no significant correlations based on the museum where respondents found the link for the study (Spearman's rho $<0.05$ in almost all cases).

When comparing survey results with the frequency of museum and museum website visits, the most notable result was the strong correlation (Spearman's rho $=0.48$ ) between the frequency with which respondents visit museums and the frequency with which respondents visit museum websites. The respondents' frequency of museum visits did not, however, correlate strongly with other survey questions, with the highest correlations found between frequency of museum visit and the likelihood of visiting museum websites before visiting a museum in one's home town $($ rho $=0.19)$ or a museum they visit regularly $(\mathrm{rho}=0.16)$; while significant according to chisquares tests, the weakness of the correlation ratio suggests that frequency of museum visits is not a major factor in determining the relationship museum visitors have with museums and museum websites (excepting perhaps museums they visit regularly or museums in their home town).

The frequency with which survey respondents visit museum websites, on the other hand, had numerous strong and significant relationships with other survey questions. For example, the 
frequency with which online visitors visit museum websites was fairly strongly correlated with the importance survey respondents place on museums having museum websites (rho $=0.36$ ), the likelihood they will visit museum websites before visiting museums (rho $=0.36$ ), and the likelihood they will visit museum websites after visiting museums (rho $=0.36$ ). Similarly, the importance survey respondents placed on museums having museum websites correlated fairly strongly with the likelihood that they will visit museum websites both before (rho $=0.41)$ and after (rho $=0.29)$ visiting museums.

\section{Discussion}

By framing the results of this research in terms of the "museum website in the life of the visitor," this article calls attention to the need for museum professionals to think critically about their websites and the information they provide from the perspective of museum visitors, before and after museum visits. As discussed above, the research methodologies necessitated by such an approach place certain limitations on the data collected, but the purpose of user studies is not necessarily that any one slice of data is generalizable to the whole, but rather that each slice of data, accumulated through multiple studies over time, helps illustrate an overall trend in museum website visitation patterns. When viewed from that perspective, this study helps to illuminate the mindset of a small but important slice of a growing population of museum visitors.

The following discussion, therefore, is not necessarily meant to apply to all museum visitors generally, but rather to the subset of online museum visitors exemplified by the survey respondents in this study. Within these limitations, the results indicate that online and in-house museum visitors are not separate entities: not only are many online museum visitors using museum websites to plan visits to physical museums, but many are also using museum websites to learn more about museums after a visit. The relationship between museums and museum websites is complementary, and one should not assume that online and in-house museum visitors need access to completely different types of information resources. When developing information resources for museum websites, it is important to consider the overlap between online and in-house museum visitors, and create resources that meet the needs of all visitors, including those planning and returning from museum visits.

The results also illustrate that online museum visitors understand the complicated relationship that exists between museums and museum websites, and have clear expectations of what they want museum websites to provide, before and after visiting a museum. Online museum visitors are increasingly living in a world where the physical and virtual intersect with and complement each other daily. For many online museum visitors, virtual and physical museum resources can play off each other such that the whole is greater that the sum of the parts. When viewed from this perspective, museum visitors will benefit most from websites that offer uniquely online features, such as interactive, online exhibits, as well as information resources that encourage a strong relationship with the physical museum, such as maps and driving directions.

At the same time, however, the need for museum websites to support online and in-house museum activities reinforces the complexity of the relationship between museums and their websites, especially since the information needs of a visitor are likely to change as that visitor goes from online to in-house and back again. The same visitor may want different things from 
the museum and the museum's website as he or she proceeds through a cycle of visiting the museum and the museum's website repeatedly. One cannot assume that visitors using a website to plan their first visit will need the same information as visitors planning their second visit, or that they will be interested in the same exhibits, collections, and so on.

By realizing the complexities of the relationships between museums, museum websites, and museum visitors, before and after visits; by understanding that information needs change as visitors move from online to in-house and back again; and by tracking these changes carefully, museum professionals can better meet the needs of all visitors. It is important for museum professionals to understand how the needs of museum visitors change over time, and the results of this study can help museum professionals cope with the changing worlds of museum visitors, online and in-house, before, during, and after museum visits.

In particular, this study demonstrates how all museum professionals (including curators, educators, web developers, etc.) can build on the lessons learned to develop and strengthen a complementary and supportive relationship between museums and museum websites.

Encouraging such a relationship is important not only because so many online museum visitors visit museum websites before and after museum visits, but also because so many online visitors use museum websites, and the information resources they provide, to make decisions about whether or not they will visit the museums in person. This discussion, therefore, concludes with three takeaway lessons for museum professionals developing museum websites.

\section{Needs and expectations of online museum visitors}

Museum professionals must understand what museum visitors are looking for on museum websites, before and after museum visits, and make these information resources available and accessible on their website (cf. Kravchyna and Hastings 2002). Online museum visitors have specific, and different, needs and expectations of museum websites before and after museum visits. Prior to a visit, for example, online visitors are more likely to need information such as hours of operation or driving directions, while after a visit, they are more likely to want information about future exhibits and special events. On the other hand, visitors are more likely to use online tours of galleries before visits than after visits, and more likely to use online images of artifacts after visits than before visits.

Differences between pre-visit and post-visit needs and expectations are crucial to understand if museum professionals are to support a complementary relationship between museums and museum websites. Given that many online visitors prior to a visit have already decided to visit the museum, it is important to encourage this already made decision. Given that most online visitors after a visit will have different needs, it important to capitalize on those differences and find ways that will draw them back in for another visit. A poorly planned and badly designed museum website can undermine the museum's ability to connect with its visitors, before and after museum visits, and it is important for museum professionals to offer information resources suitable for the increasing number of museum visitors using museum websites to augment the physical museum visit (cf. Bowen, Bennet, and Johnson 1998).

\section{Circumstances that prompt online museum visits}


Museum professionals must understand the situations in which online museum visitors are likely to visit museum websites, before and after visiting museums, and use these circumstances to their advantage when planning museum websites (cf. Thomas and Carey 2005). While the results of the survey indicate that online museum visitors are very likely to visit museum websites both before and after museum visits, they are more likely to do so in some situations than others, and it is important for museum professionals planning websites to understand the differences if they are to capitalize on the circumstances that encourage online visitors to visit in person.

When viewed from this perspective, it is important to design websites that specifically help those visitors who may be looking for museums to visit while on vacation, are visiting museums unfamiliar to them, or visiting museums where the exhibits change frequently (cf. Bowen 1999). As each of these situations will likely require different approaches to website design, it is important for museum webmasters to carefully study their representative online visitors as well as the situations in which they are more or less likely to visit museum websites before and after museum visits. Along these lines, it is even possible that a well-designed website will have the potential to recruit brand new visitors for a museum, including those individuals who rarely, if ever, visit museums in person.

\section{Characteristics of museum websites that influence museum visits}

Museum professionals must understand the characteristics of museum websites that are likely to influence online museum visitors to visit a museum, and ensure their websites employ these characteristics in ways that positively influence their museum's visitors. Given that the majority of online museum visitors are likely to use the museum's website to determine whether they want to visit the museum in person, the design, development, and presentation of museum websites is of great importance (cf. Haley Goldman and Schaller 2004). The finding that nearly one in five of the survey respondents reported that they had decided not to visit a museum specifically because of its website underscores the website's significance for the museum.

Certain characteristics of museum websites are more likely to influence museum visits than others, and it is critical for museum professionals to understand these differences (cf. Herman, Johnson, and Ockuly 2004). For example, the results of the survey indicate that for many online museum visitors, the ability to search the museum's collections (an area of great effort for many museum professionals) is not necessarily as important as the overall quality of the available information. Efforts to improve information quality throughout the entire site, therefore, may more positively influence online museum visitors than efforts to increase the amount of collections data available online.

Despite the importance of these lessons, the most valuable lesson of this research may be that reading about the results of research studies is not enough; museum professionals still need to conduct their own user studies to learn as much as possible about their own visitors, online and in-house. While the results of this study provide important findings about the relationships online museum visitors have with museums and museum websites, museum professionals should not attempt to apply the results of this research without first validating them with their own unique set of museum visitors; nothing can replace running one's own study on one's own website. 


\section{Conclusions}

The results of this study offer positive lessons for museums and museum professionals attempting to build strong relationships with their visitors, online and in-house. The majority of online museum visitors understand the role of the website in encouraging this relationship, and are interested in developing a complementary relationship with the museums and museum websites they visit. Museum professionals should encourage their visitors by developing websites that support their needs and expectations before, during, and after museum visits. Doing so effectively means not neglecting the basic information resources that allow cyclical, complementary relationships to build and develop.

These kinds of positive relationships are capable of building on their own, and the current state of museum websites in the lives of museum visitors seems to be working fairly well. Museum visitors know what they want in-house and online, and museum professionals are actively working to meet those needs and expectations. While online museum visitors may judge a museum based on its website, they know that the real prize lies in the museum, and they are not interested in supplanting physical museums with virtual ones. Therefore, by developing complementary resources that work together, online and in-house, to support the needs of all museum visitors, museum professionals will encourage more museum visits, and stronger relationships between museums and their visitors.

\section{Acknowledgements}

The author would like to acknowledge the assistance of the museum professionals who promoted this study by linking to the online survey from their museums' websites; without their assistance, this project would never have reached such an international and broad range of online museum visitors. The author would also like to acknowledge the contributions of the anonymous reviewers whose suggestions helped to improve this manuscript.

\section{References}

Adams, C., T. Cole, C. DePaolo, and S. Edwards. 2001. Bringing the curatorial process to the web. In Museums and the Web 2001, edited by D. Bearman and J. Trant, 11-22. Pittsburgh, PA: Archives \& Museum Informatics. http://www.archimuse.com/mw2001/papers/depaolo/depaola.html

Andrews, D., B. Nonnecke, and J. Preece. 2003. Electronic survey methodology: A case study in reaching hard to involve Internet users. International Journal of Human-Computer Interaction 16 (2): 185-210.

Besser, H. 1997. The transformation of the museum and the way it's perceived. In The wired museum: Emerging technology and changing paradigms, edited by K. Jones-Garmil, 153-170. Washington, D.C.: American Association of Museums. 
Booth, B. 1999. Understanding the information needs of visitors to museums. Museum Management and Curatorship 17 (2): 139-157.

Bowen, J., J. Bennet, and J. Johnson. 1998. Virtual visits to virtual museums. In Museums and the Web 1998, edited by D. Bearman and J. Trant. Pittsburgh, PA: Archives \& Museum Informatics. http://www.archimuse.com/mw98/papers/bowen/bowen_paper.html

Bowen, J. 1999. Time for renovations: a survey of museum web sites. In Museums and the Web 1999, edited by D. Bearman and J. Trant, 163-174. Pittsburgh, PA: Archives \& Museum Informatics. http://www.archimuse.com/mw99/papers/bowen/bowen.html

Bowen, J., and S. Filippini-Fantoni. 2004. Personalization and the web from a museum perspective. In Museums and the Web 2004, edited by D. Bearman and J. Trant, 63-78. Toronto, Canada: Archives \& Museum Informatics. http://www.archimuse.com/mw2004/papers/bowen/bowen.html

Cameron, F. 2003. Digital Futures I: Museum collections, digital technologies, and the cultural construction of knowledge. Curator 46: 325-340.

Chadwick, J. and P. Boverie. 1999. A survey of characteristics and patterns of behavior in visitors to a museum web site. In Museums and the Web 1999, edited by D. Bearman and J. Trant, 154-162. Pittsburgh, PA: Archives \& Museum Informatics. http://www.archimuse.com/mw99/papers/chadwick/chadwick.html

Coburn, E. and M. Baca. 2004. Beyond the gallery walls: Tools and methods for leading endusers to collections information. Bulletin of the American Society for Information Science and Technology 30 (5): 14-19.

Couper, M.P. 2000. Web-based surveys: A review of issues and approaches. Public Opinion Quarterly 64: 464-494.

Cunliffe, D., E. Kritou, and D. Tudhope. 2001. Usability evaluation for museum Web sites. Museum Management and Curatorship 19: 229-252.

Douma, M. and M. Henchman. 2000. Bringing the object to the viewer: Multimedia techniques for the scientific study of art. In Museums and the Web 2000, edited by D. Bearman and J. Trant, 59-64. Pittsburgh, PA: Archives \& Museum Informatics. http://www.archimuse.com/mw2000/papers/doumahenchman/doumahenchman.html

Dyson, M. and K. Moran. 2000. Informing the design of Web interfaces to museum collections. Museum Management and Curatorship 18: 391-406.

Falk, J.H. 2006. The impact of visit motivation on learning: Using identity as a construct to understand the visitor experience. Curator 49 (2): 151-166.

Falk, J.H. and L.D. Dierking. 2000. Learning from museums: Visitor experiences and the making 
of meaning. Walnut Creek, CA: AltaMira Press.

Galani, A. and M. Chalmers. 2002. Can you see me? Exploring co-visiting between physical and virtual visitors. In Museums and the Web 2002, edited by D. Bearman and J. Trant, 3140. Pittsburgh, PA: Archives \& Museum Informatics. http://www.archimuse.com/mw2002/papers/galani/galani.html

Gillard, P. 2002. Cruising through History Wired. In Museums and the Web 2002, edited by D. Bearman and J. Trant. Pittsburgh, PA: Archives \& Museum Informatics. http://www.archimuse.com/mw2002/papers/gillard/gillard.html

Haley Goldman, K. and D. Schaller. 2004. Exploring motivational factors and visitor satisfaction in on-line museum visits. In Museums and the Web 2004, edited by D. Bearman and J. Trant, 223-235. Toronto, CA: Archives and Museum Informatics. http://www.archimuse.com/mw2004/papers/haleyGoldman/haleyGoldman.html

Haley Goldman, K. and M. Wadman. 2002. There's something happening here, What it is ain't exactly clear. In Museums and the Web 2002, ed. D. Bearman and J. Trant. Pittsburgh, PA: Archives \& Museum Informatics. http://www.archimuse.com/mw2002/papers/haleyGoldman/haleygoldman.html

Hamma, K. 2004. The role of museums in online teaching, learning, and research. First Monday 9 (5): http://firstmonday.org/issues/issue9_5/hamma

Herman, D.L., K. Johnson, and J. Ockuly. 2004. What clicked? An interim report on audience research and media resources. In Museums and the Web 2004, edited by D. Bearman and J. Trant. Toronto, CA: Archives and Museum Informatics. http://www.archimuse.com/mw2004/papers/ockuly/ockuly.html

Knell, S. 2003. The shape of things to come: Museums in the technological landscape. Museum and Society 1 (3): 132-146.

Kravchyna, V. and S. Hastings. 2002. Informational value of museum web sites. First Monday 7 (2): http://www.firstmonday.org/issues/issue7_2/kravchyna

Lynch, C. 2002. Digital collections, digital libraries, and the digitization of cultural heritage information. First Monday 7 (5): http://www.firstmonday.org/issues/issue7_5/lynch

Marty, P.F. 2007. The changing nature of information work in museums. Journal of the American Society for Information Science and Technology 58 (1): 97-107.

McKenzie, J. 1997. Building a virtual museum community. In Museums and the Web 1997, edited by D. Bearman and J. Trant, 77-91. Pittsburgh, PA: Archives \& Museum Informatics.

Müller, K. 2002. Museums and virtuality. Curator 45 (1): 21-33. 
Sarraf, S. 1999. A survey of museums on the web: Who uses museum websites? Curator 42: 231-243.

Sayre, S. 2000. Sharing the experience: The building of a successful online/on-site exhibition. In Museums and the Web 2000, edited by D. Bearman and J. Trant, 13-20. Pittsburgh, PA: Archives \& Museum Informatics. http://www.archimuse.com/mw2000/papers/sayre/sayre.html

Sen, A., P. Dacin, and C. Pattichis. 2006. Current trends in web data analysis. Communications of the ACM 49 (11): 85-91.

Taxén, G. and E. Frécon. 2005. The extended museum visit: Documenting and exhibiting postvisit experiences. In Museums and the Web 2005, edited by D. Bearman and J. Trant, n.p. Toronto, CA: Archives and Museum Informatics. http://www.archimuse.com/mw2005/papers/taxen/taxen.html

Thomas, W.A. and S. Carey. 2005. Actual/virtual visits: What are the links? In Museums and the Web 2005, edited by D. Bearman and J. Trant. Toronto, CA: Archives and Museum Informatics. http://www.archimuse.com/mw2005/papers/thomas/thomas.html

\begin{abstract}
About the Author
Paul F. Marty is Assistant Professor in the College of Information at Florida State University. He has a background in ancient history and computer science engineering, and his Ph.D. is from the Graduate School of Library and Information Science at the University of Illinois at UrbanaChampaign. Before arriving at FSU, he was Director of Information Technology at the University of Illinois' Spurlock Museum. His current research focuses on the evolution of sociotechnical systems and collaborative work practices in museums, the usability of museum websites, the evolving roles of information professionals in museums, and the digital museum in the life of the user.
\end{abstract}




\begin{tabular}{|l|c|c|c|c|c|c|}
\hline & $\begin{array}{c}\text { Very } \\
\text { Unlikely }\end{array}$ & Unlikely & Neutral & Likely & $\begin{array}{c}\text { Very } \\
\text { Likely }\end{array}$ & n \\
\hline $\begin{array}{l}\text { In general, before visiting a museum, } \\
\text { how likely are you to visit the } \\
\text { museum's website? }\end{array}$ & $\begin{array}{c}3.2 \% \\
(37)\end{array}$ & $\begin{array}{c}4.5 \% \\
(53)\end{array}$ & $\begin{array}{c}10.3 \% \\
(120)\end{array}$ & $\begin{array}{c}29.2 \% \\
(341)\end{array}$ & $\begin{array}{c}52.7 \% \\
(615)\end{array}$ & 1166 \\
\hline
\end{tabular}

Table 1: Visiting museum websites before visiting museums in general

\begin{tabular}{|c|c|c|c|c|c|c|}
\hline $\begin{array}{l}\text { In each of the following situations, } \\
\text { how likely are you to visit a museum's } \\
\text { website before visiting the museum? }\end{array}$ & $\begin{array}{l}\text { Very } \\
\text { Unlikely }\end{array}$ & Unlikely & Neutral & Likely & $\begin{array}{l}\text { Very } \\
\text { Likely }\end{array}$ & $\mathbf{n}$ \\
\hline $\begin{array}{l}\text { You are visiting a museum you visit } \\
\text { regularly }\end{array}$ & $\begin{array}{c}5.4 \% \\
(63)\end{array}$ & $\begin{array}{c}16.0 \% \\
(188)\end{array}$ & $\begin{array}{l}19.1 \% \\
(225)\end{array}$ & $\begin{array}{c}37.8 \% \\
(444)\end{array}$ & $\begin{array}{c}21.7 \% \\
(255)\end{array}$ & 1175 \\
\hline $\begin{array}{l}\text { You are visiting a museum unfamiliar } \\
\text { to you }\end{array}$ & $\begin{array}{c}2.1 \% \\
(25)\end{array}$ & $\begin{array}{c}2.7 \% \\
(32)\end{array}$ & $\begin{array}{c}6.1 \% \\
(72)\end{array}$ & $\begin{array}{c}21.7 \% \\
(254)\end{array}$ & $\begin{array}{c}67.3 \% \\
(789)\end{array}$ & 1172 \\
\hline You are visiting a museum by yourself & $\begin{array}{c}3.3 \% \\
(39)\end{array}$ & $\begin{array}{c}4.7 \% \\
(55)\end{array}$ & $\begin{array}{c}14.0 \% \\
(164)\end{array}$ & $\begin{array}{c}32.6 \% \\
(382)\end{array}$ & $\begin{array}{l}45.3 \% \\
(530)\end{array}$ & 1170 \\
\hline $\begin{array}{l}\text { You are visiting a museum with friends } \\
\text { or family }\end{array}$ & $\begin{array}{c}2.6 \% \\
(30)\end{array}$ & $\begin{array}{c}4.0 \% \\
(46)\end{array}$ & $\begin{array}{c}13.0 \% \\
(151)\end{array}$ & $\begin{array}{c}34.9 \% \\
(406)\end{array}$ & $\begin{array}{l}45.6 \% \\
(531)\end{array}$ & 1164 \\
\hline $\begin{array}{l}\text { You are visiting a museum in your } \\
\text { home town }\end{array}$ & $\begin{array}{c}5.5 \% \\
(65)\end{array}$ & $\begin{array}{l}12.7 \% \\
(149)\end{array}$ & $\begin{array}{c}20.1 \% \\
(236)\end{array}$ & $\begin{array}{c}37.8 \% \\
(444)\end{array}$ & $\begin{array}{c}23.9 \% \\
(280)\end{array}$ & 1174 \\
\hline $\begin{array}{l}\text { You are visiting a museum while } \\
\text { traveling or on vacation }\end{array}$ & $\begin{array}{c}2.9 \% \\
(34)\end{array}$ & $\begin{array}{c}7.1 \% \\
(83)\end{array}$ & $\begin{array}{l}9.1 \% \\
(107)\end{array}$ & $\begin{array}{c}21.4 \% \\
(251)\end{array}$ & $\begin{array}{l}59.6 \% \\
(700)\end{array}$ & 1175 \\
\hline $\begin{array}{l}\text { You are visiting a museum where the } \\
\text { exhibits change frequently }\end{array}$ & $\begin{array}{c}2.0 \% \\
(24)\end{array}$ & $\begin{array}{c}2.6 \% \\
(30)\end{array}$ & $\begin{array}{l}7.2 \% \\
(85)\end{array}$ & $\begin{array}{c}27.1 \% \\
(318)\end{array}$ & $\begin{array}{c}61.1 \% \\
(717)\end{array}$ & 1174 \\
\hline $\begin{array}{l}\text { You are visiting a museum where there } \\
\text { is too much to see in one visit }\end{array}$ & $\begin{array}{c}2.3 \% \\
(27)\end{array}$ & $\begin{array}{c}3.1 \% \\
(36)\end{array}$ & $\begin{array}{c}11.1 \% \\
(131)\end{array}$ & $\begin{array}{c}27.5 \% \\
(324)\end{array}$ & $\begin{array}{c}56.0 \% \\
(659)\end{array}$ & 1177 \\
\hline
\end{tabular}

Table 2: Visiting museum websites before visiting museums in specific situations 


\begin{tabular}{|c|c|c|c|c|c|c|}
\hline $\begin{array}{l}\text { When visiting a museum's website } \\
\text { before visiting the museum, how likely } \\
\text { are you to use each of the following } \\
\text { resources? }\end{array}$ & $\begin{array}{c}\text { Very } \\
\text { Unlikely }\end{array}$ & Unlikely & Neutral & Likely & $\begin{array}{l}\text { Very } \\
\text { Likely }\end{array}$ & $\mathbf{n}$ \\
\hline $\begin{array}{l}\text { Online images of artifacts / collections } \\
\text { data }\end{array}$ & $\begin{array}{c}3.8 \% \\
(44)\end{array}$ & $\begin{array}{l}9.5 \% \\
(110)\end{array}$ & $\begin{array}{c}17.4 \% \\
(201)\end{array}$ & $\begin{array}{c}33.2 \% \\
(384)\end{array}$ & $\begin{array}{c}36.1 \% \\
(417)\end{array}$ & 1156 \\
\hline $\begin{array}{l}\text { Online tours of galleries / interactive } \\
\text { exhibits }\end{array}$ & $\begin{array}{c}4.7 \% \\
(55)\end{array}$ & $\begin{array}{l}13.4 \% \\
(155)\end{array}$ & $\begin{array}{c}20.9 \% \\
(242)\end{array}$ & $\begin{array}{c}34.4 \% \\
(398)\end{array}$ & $\begin{array}{c}26.6 \% \\
(308)\end{array}$ & 1158 \\
\hline $\begin{array}{l}\text { Online educational activities / learning } \\
\text { resources }\end{array}$ & $\begin{array}{c}6.7 \% \\
(77)\end{array}$ & $\begin{array}{l}19.5 \% \\
(224)\end{array}$ & $\begin{array}{c}30.7 \% \\
(353)\end{array}$ & $\begin{array}{c}26.0 \% \\
(299)\end{array}$ & $\begin{array}{c}17.2 \% \\
(198)\end{array}$ & 1151 \\
\hline Online research materials / archives & $\begin{array}{c}5.1 \% \\
(59)\end{array}$ & $\begin{array}{l}16.0 \% \\
(183)\end{array}$ & $\begin{array}{c}24.9 \% \\
(286)\end{array}$ & $\begin{array}{c}25.7 \% \\
(295)\end{array}$ & $\begin{array}{c}28.2 \% \\
(324)\end{array}$ & 1147 \\
\hline $\begin{array}{l}\text { Information about hours of operation / } \\
\text { location / directions }\end{array}$ & $\begin{array}{c}1.9 \% \\
(22)\end{array}$ & $\begin{array}{l}1.5 \% \\
(17)\end{array}$ & $\begin{array}{c}3.9 \% \\
(45)\end{array}$ & $\begin{array}{c}20.4 \% \\
(237)\end{array}$ & $\begin{array}{l}72.3 \% \\
(838)\end{array}$ & 1159 \\
\hline $\begin{array}{l}\text { Information about admission fees / } \\
\text { pricing }\end{array}$ & $\begin{array}{c}2.5 \% \\
(29)\end{array}$ & $\begin{array}{c}2.8 \% \\
(32)\end{array}$ & $\begin{array}{l}7.5 \% \\
(87)\end{array}$ & $\begin{array}{c}22.0 \% \\
(254)\end{array}$ & $\begin{array}{c}65.2 \% \\
(752)\end{array}$ & 1154 \\
\hline $\begin{array}{l}\text { Information about museum facilities / } \\
\text { gift shop / restaurants }\end{array}$ & $\begin{array}{c}5.3 \% \\
(61)\end{array}$ & $\begin{array}{l}10.4 \% \\
(120)\end{array}$ & $\begin{array}{c}20.1 \% \\
(232)\end{array}$ & $\begin{array}{c}29.5 \% \\
(340)\end{array}$ & $\begin{array}{c}34.7 \% \\
(400)\end{array}$ & 1153 \\
\hline $\begin{array}{l}\text { Information about current and future } \\
\text { exhibits }\end{array}$ & $\begin{array}{c}2.5 \% \\
(29)\end{array}$ & $\begin{array}{c}1.1 \% \\
(13)\end{array}$ & $\begin{array}{c}4.5 \% \\
(52)\end{array}$ & $\begin{array}{c}27.6 \% \\
(319)\end{array}$ & $\begin{array}{c}64.2 \% \\
(741)\end{array}$ & 1154 \\
\hline $\begin{array}{l}\text { Information about programs / tours / } \\
\text { special events }\end{array}$ & $\begin{array}{c}3.4 \% \\
(39)\end{array}$ & $\begin{array}{l}3.8 \% \\
(44)\end{array}$ & $\begin{array}{c}13.1 \% \\
(151)\end{array}$ & $\begin{array}{c}31.8 \% \\
(366)\end{array}$ & $\begin{array}{c}47.9 \% \\
(551)\end{array}$ & 1151 \\
\hline $\begin{array}{l}\text { Information about employment / } \\
\text { volunteer opportunities }\end{array}$ & $\begin{array}{l}22.7 \% \\
(260)\end{array}$ & $\begin{array}{c}25.2 \% \\
(288)\end{array}$ & $\begin{array}{c}27.6 \% \\
(316)\end{array}$ & $\begin{array}{c}13.4 \% \\
(153)\end{array}$ & $\begin{array}{l}11.0 \% \\
(126)\end{array}$ & 1143 \\
\hline $\begin{array}{l}\text { Information about donation / } \\
\text { membership opportunities }\end{array}$ & $\begin{array}{c}15.5 \% \\
(178)\end{array}$ & $\begin{array}{c}21.1 \% \\
(242)\end{array}$ & $\begin{array}{c}36.2 \% \\
(414)\end{array}$ & $\begin{array}{c}19.9 \% \\
(228)\end{array}$ & $\begin{array}{l}7.2 \% \\
(83)\end{array}$ & 1145 \\
\hline
\end{tabular}

Table 3: Use of online resources when visiting museum websites before visiting museums 


\begin{tabular}{|l|c|c|c|c|c|c|}
\hline & $\begin{array}{c}\text { Very } \\
\text { Unlikely }\end{array}$ & Unlikely & Neutral & Likely & $\begin{array}{c}\text { Very } \\
\text { Likely }\end{array}$ & n \\
\hline $\begin{array}{l}\text { In general, after visiting a museum, } \\
\text { how likely are you to visit the } \\
\text { museum's website? }\end{array}$ & $\begin{array}{c}3.0 \% \\
(31)\end{array}$ & $\begin{array}{c}7.0 \% \\
(72)\end{array}$ & $\begin{array}{c}20.4 \% \\
(209)\end{array}$ & $\begin{array}{c}39.8 \% \\
(408)\end{array}$ & $\begin{array}{c}29.7 \% \\
(304)\end{array}$ & 1024 \\
\hline
\end{tabular}

Table 4: Visiting museum websites after visiting museums in general

\begin{tabular}{|l|c|c|c|c|c|c|}
\hline $\begin{array}{l}\text { In each of the following situations, } \\
\text { how likely are you to visit a museum's } \\
\text { website after visiting the museum? }\end{array}$ & $\begin{array}{c}\text { Very } \\
\text { Unlikely }\end{array}$ & Unlikely & Neutral & Likely & $\begin{array}{c}\text { Very } \\
\text { Likely }\end{array}$ & n \\
\hline $\begin{array}{l}\text { You were visiting a museum you visit } \\
\text { regularly }\end{array}$ & $\begin{array}{c}5.3 \% \\
(55)\end{array}$ & $\begin{array}{c}15.9 \% \\
(164)\end{array}$ & $\begin{array}{c}21.0 \% \\
(216)\end{array}$ & $\begin{array}{c}37.0 \% \\
(381)\end{array}$ & $\begin{array}{c}20.9 \% \\
(215)\end{array}$ & 1031 \\
\hline $\begin{array}{l}\text { You were visiting a museum } \\
\text { unfamiliar to you }\end{array}$ & $\begin{array}{c}2.9 \% \\
(30)\end{array}$ & $\begin{array}{c}7.7 \% \\
(80)\end{array}$ & $\begin{array}{c}17.3 \% \\
(179)\end{array}$ & $\begin{array}{c}41.6 \% \\
(430)\end{array}$ & $\begin{array}{c}30.4 \% \\
(314)\end{array}$ & 1033 \\
\hline $\begin{array}{l}\text { You were visiting a museum by } \\
\text { yourself }\end{array}$ & $\begin{array}{c}3.4 \% \\
(35)\end{array}$ & $\begin{array}{c}8.1 \% \\
(83)\end{array}$ & $\begin{array}{c}29.3 \% \\
(301)\end{array}$ & $\begin{array}{c}36.0 \% \\
(370)\end{array}$ & $\begin{array}{c}23.3 \% \\
(240)\end{array}$ & 1029 \\
\hline $\begin{array}{l}\text { You were visiting a museum with } \\
\text { friends or family }\end{array}$ & $\begin{array}{c}3.9 \% \\
(40)\end{array}$ & $\begin{array}{c}9.5 \% \\
(97)\end{array}$ & $\begin{array}{c}31.6 \% \\
(323)\end{array}$ & $\begin{array}{c}36.1 \% \\
(369)\end{array}$ & $\begin{array}{c}18.9 \% \\
(193)\end{array}$ & 1022 \\
\hline $\begin{array}{l}\text { You were visiting a museum in your } \\
\text { home town }\end{array}$ & $\begin{array}{c}5.7 \% \\
(59)\end{array}$ & $\begin{array}{c}15.8 \% \\
(162)\end{array}$ & $\begin{array}{c}30.7 \% \\
(315)\end{array}$ & $\begin{array}{c}32.7 \% \\
(336)\end{array}$ & $\begin{array}{c}15.1 \% \\
(155)\end{array}$ & 1027 \\
\hline $\begin{array}{l}\text { You were visiting a museum while } \\
\text { traveling or on vacation }\end{array}$ & $\begin{array}{c}3.5 \% \\
(36)\end{array}$ & $\begin{array}{c}8.7 \% \\
(90)\end{array}$ & $\begin{array}{c}17.2 \% \\
(177)\end{array}$ & $\begin{array}{c}36.2 \% \\
(373)\end{array}$ & $\begin{array}{c}34.4 \% \\
(354)\end{array}$ & 1030 \\
\hline $\begin{array}{l}\text { You were visiting a museum where the } \\
\text { exhibits change frequently }\end{array}$ & $\begin{array}{c}2.4 \% \\
(24)\end{array}$ & $\begin{array}{c}4.0 \% \\
(41)\end{array}$ & $\begin{array}{c}14.6 \% \\
(149)\end{array}$ & $\begin{array}{c}41.6 \% \\
(425)\end{array}$ & $\begin{array}{c}37.4 \% \\
(382)\end{array}$ & 1021 \\
\hline $\begin{array}{l}\text { You were visiting a museum where } \\
\text { there is too much to see in one visit }\end{array}$ & $\begin{array}{c}2.5 \% \\
(26)\end{array}$ & $\begin{array}{c}4.8 \% \\
(49)\end{array}$ & $\begin{array}{c}13.1 \% \\
(135)\end{array}$ & $\begin{array}{c}37.3 \% \\
(385)\end{array}$ & $\begin{array}{c}42.3 \% \\
(436)\end{array}$ & 1031 \\
\hline
\end{tabular}

Table 5: Visiting museum websites after visiting museums in specific situations 


\begin{tabular}{|c|c|c|c|c|c|c|}
\hline $\begin{array}{l}\text { When visiting a museum's website } \\
\text { after visiting the museum, how likely } \\
\text { are you to use each of the following } \\
\text { resources? }\end{array}$ & $\begin{array}{l}\text { Very } \\
\text { Unlikely }\end{array}$ & Unlikely & Neutral & Likely & $\begin{array}{l}\text { Very } \\
\text { Likely }\end{array}$ & $\mathbf{n}$ \\
\hline $\begin{array}{l}\text { Online images of artifacts / collections } \\
\text { data }\end{array}$ & $\begin{array}{c}3.6 \% \\
(37)\end{array}$ & $\begin{array}{l}8.2 \% \\
(83)\end{array}$ & $\begin{array}{c}15.8 \% \\
(161)\end{array}$ & $\begin{array}{c}40.4 \% \\
(410)\end{array}$ & $\begin{array}{c}32.0 \% \\
(325)\end{array}$ & 1016 \\
\hline $\begin{array}{l}\text { Online tours of galleries / interactive } \\
\text { exhibits }\end{array}$ & $\begin{array}{c}4.7 \% \\
(48)\end{array}$ & $\begin{array}{l}15.1 \% \\
(153)\end{array}$ & $\begin{array}{c}26.3 \% \\
(266)\end{array}$ & $\begin{array}{c}35.5 \% \\
(359)\end{array}$ & $\begin{array}{c}18.3 \% \\
(185)\end{array}$ & 1011 \\
\hline $\begin{array}{l}\text { Online educational activities / learning } \\
\text { resources }\end{array}$ & $\begin{array}{c}4.8 \% \\
(48)\end{array}$ & $\begin{array}{l}12.1 \% \\
(122)\end{array}$ & $\begin{array}{l}29.3 \% \\
(296)\end{array}$ & $\begin{array}{c}35.8 \% \\
(362)\end{array}$ & $\begin{array}{c}18.0 \% \\
(182)\end{array}$ & 1010 \\
\hline Online research materials / archives & $\begin{array}{c}3.7 \% \\
(37)\end{array}$ & $\begin{array}{c}8.5 \% \\
(86)\end{array}$ & $\begin{array}{c}20.8 \% \\
(209)\end{array}$ & $\begin{array}{c}36.1 \% \\
(363)\end{array}$ & $\begin{array}{c}30.9 \% \\
(311)\end{array}$ & 1006 \\
\hline $\begin{array}{l}\text { Information about hours of operation / } \\
\text { location / directions }\end{array}$ & $\begin{array}{c}14.7 \% \\
(149)\end{array}$ & $\begin{array}{c}24.1 \% \\
(244)\end{array}$ & $\begin{array}{l}28.6 \% \\
(289)\end{array}$ & $\begin{array}{c}22.3 \% \\
(225)\end{array}$ & $\begin{array}{l}10.3 \% \\
(104)\end{array}$ & 1011 \\
\hline $\begin{array}{l}\text { Information about admission fees / } \\
\text { pricing }\end{array}$ & $\begin{array}{c}16.0 \% \\
(161)\end{array}$ & $\begin{array}{c}26.9 \% \\
(271)\end{array}$ & $\begin{array}{l}28.2 \% \\
(284)\end{array}$ & $\begin{array}{c}19.3 \% \\
(194)\end{array}$ & $\begin{array}{c}9.6 \% \\
(97)\end{array}$ & 1007 \\
\hline $\begin{array}{l}\text { Information about museum facilities / } \\
\text { gift shop / restaurants }\end{array}$ & $\begin{array}{l}15.6 \% \\
(158)\end{array}$ & $\begin{array}{c}26.5 \% \\
(268)\end{array}$ & $\begin{array}{c}31.5 \% \\
(318)\end{array}$ & $\begin{array}{c}17.6 \% \\
(178)\end{array}$ & $\begin{array}{l}8.7 \% \\
(88)\end{array}$ & 1010 \\
\hline $\begin{array}{l}\text { Information about current and future } \\
\text { exhibits }\end{array}$ & $\begin{array}{c}3.4 \% \\
(34)\end{array}$ & $\begin{array}{c}3.7 \% \\
(37)\end{array}$ & $\begin{array}{c}13.3 \% \\
(134)\end{array}$ & $\begin{array}{c}48.3 \% \\
(487)\end{array}$ & $\begin{array}{c}31.3 \% \\
(316)\end{array}$ & 1008 \\
\hline $\begin{array}{l}\text { Information about programs / tours / } \\
\text { special events }\end{array}$ & $\begin{array}{c}5.6 \% \\
(56)\end{array}$ & $\begin{array}{c}8.0 \% \\
(80)\end{array}$ & $\begin{array}{c}17.9 \% \\
(179)\end{array}$ & $\begin{array}{c}44.0 \% \\
(440)\end{array}$ & $\begin{array}{c}24.5 \% \\
(245)\end{array}$ & 1000 \\
\hline $\begin{array}{l}\text { Information about employment / } \\
\text { volunteer opportunities }\end{array}$ & $\begin{array}{c}17.9 \% \\
(181)\end{array}$ & $\begin{array}{l}18.4 \% \\
(186)\end{array}$ & $\begin{array}{c}34.2 \% \\
(345)\end{array}$ & $\begin{array}{c}19.6 \% \\
(198)\end{array}$ & $\begin{array}{c}9.8 \% \\
(99)\end{array}$ & 1009 \\
\hline $\begin{array}{l}\text { Information about donation / } \\
\text { membership opportunities }\end{array}$ & $\begin{array}{c}15.5 \% \\
(157)\end{array}$ & $\begin{array}{c}18.5 \% \\
(187)\end{array}$ & $\begin{array}{c}39.8 \% \\
(403)\end{array}$ & $\begin{array}{c}19.7 \% \\
(199)\end{array}$ & $\begin{array}{l}6.5 \% \\
(66)\end{array}$ & 1012 \\
\hline
\end{tabular}

Table 6: Use of online resources when visiting museum websites after visiting museums 


\begin{tabular}{|l|c|c|c|}
\hline & No & Yes & n \\
\hline $\begin{array}{l}\text { Have you ever decided to visit a museum specifically because of its } \\
\text { website? }\end{array}$ & $\begin{array}{c}60.4 \% \\
(691)\end{array}$ & $\begin{array}{c}39.6 \% \\
(453)\end{array}$ & 1144 \\
\hline $\begin{array}{l}\text { Have you ever decided NOT to visit a museum specifically because of its } \\
\text { website? }\end{array}$ & $\begin{array}{c}80.3 \% \\
(916)\end{array}$ & $\begin{array}{c}19.7 \% \\
(225)\end{array}$ & 1141 \\
\hline
\end{tabular}

Table 7: Influence of museum websites on museum visits

\begin{tabular}{|l|c|c|c|c|c|c|}
\hline & $\begin{array}{c}\text { Very } \\
\text { Unlikely }\end{array}$ & Unlikely & Neutral & Likely & $\begin{array}{c}\text { Very } \\
\text { Likely }\end{array}$ & n \\
\hline $\begin{array}{l}\text { How likely are you to use a museum's } \\
\text { website to decide whether you want to } \\
\text { visit that museum? }\end{array}$ & $\begin{array}{c}4.1 \% \\
(47)\end{array}$ & $\begin{array}{c}9.8 \% \\
(112)\end{array}$ & $\begin{array}{c}16.1 \% \\
(184)\end{array}$ & $\begin{array}{c}37.5 \% \\
(428)\end{array}$ & $\begin{array}{c}32.4 \% \\
(370)\end{array}$ & 1141 \\
\hline
\end{tabular}

Table 8: Use of museum websites to decide on museum visits

\begin{tabular}{|l|c|c|c|c|c|c|}
\hline $\begin{array}{l}\text { How likely are each of the following } \\
\text { characteristics of museum websites to } \\
\text { influence your decision to visit (or not } \\
\text { visit) a museum? }\end{array}$ & $\begin{array}{c}\text { Very } \\
\text { Unlikely }\end{array}$ & Unlikely & Neutral & Likely & $\begin{array}{c}\text { Very } \\
\text { Likely }\end{array}$ & n \\
\hline Quality of information available & $\begin{array}{c}3.2 \% \\
(36)\end{array}$ & $\begin{array}{c}4.6 \% \\
(52)\end{array}$ & $\begin{array}{c}15.0 \% \\
(171)\end{array}$ & $\begin{array}{c}36.2 \% \\
(412)\end{array}$ & $\begin{array}{c}41.0 \% \\
(467)\end{array}$ & 1138 \\
\hline Quality of images / graphics & $\begin{array}{c}3.9 \% \\
(44)\end{array}$ & $\begin{array}{c}7.7 \% \\
(88)\end{array}$ & $\begin{array}{c}26.2 \% \\
(298)\end{array}$ & $\begin{array}{c}33.5 \% \\
(381)\end{array}$ & $\begin{array}{c}28.7 \% \\
(327)\end{array}$ & 1138 \\
\hline Ability to navigate / browse website & $\begin{array}{c}3.7 \% \\
(42)\end{array}$ & $\begin{array}{c}8.5 \% \\
(97)\end{array}$ & $\begin{array}{c}25.4 \% \\
(288)\end{array}$ & $\begin{array}{c}33.4 \% \\
(379)\end{array}$ & $\begin{array}{c}29.0 \% \\
(330)\end{array}$ & 1136 \\
\hline Ability to search website / collections & $\begin{array}{c}4.0 \% \\
(45)\end{array}$ & $\begin{array}{c}10.1 \% \\
(115)\end{array}$ & $\begin{array}{c}26.1 \% \\
(297)\end{array}$ & $\begin{array}{c}31.1 \% \\
(354)\end{array}$ & $\begin{array}{c}28.7 \% \\
(326)\end{array}$ & 1137 \\
\hline Ease of use / usability / accessibility of \\
website & $\begin{array}{c}3.7 \% \\
(42)\end{array}$ & $\begin{array}{c}8.0 \% \\
(91)\end{array}$ & $\begin{array}{c}23.5 \% \\
(266)\end{array}$ & $\begin{array}{c}34.9 \% \\
(396)\end{array}$ & $\begin{array}{c}29.9 \% \\
(339)\end{array}$ & 1134 \\
\hline Performance / efficiency / reliability of \\
website & $\begin{array}{c}3.9 \% \\
(44)\end{array}$ & $\begin{array}{c}7.8 \% \\
(89)\end{array}$ & $\begin{array}{c}24.6 \% \\
(279)\end{array}$ & $\begin{array}{c}35.2 \% \\
(399)\end{array}$ & $\begin{array}{c}28.5 \% \\
(324)\end{array}$ & 1135 \\
\hline
\end{tabular}

Table 9: Characteristics of museum websites that influence decision to visit museums 